\title{
"Haluan oppia siitä, mitä ei vielä ole"
}

\author{
Helsinkiläinen Juhana Rantavuori, 48, \\ hyödyntää väitöstutkimuksessaan harrastustaan, \\ kaupunkiaktivismia.
}

MINUSTA TULI TUTKIJA, koska tein pro graduni opettajaopiskelijoiden oppimisesta ryhmäsuunnittelutilanteessa. Ohjaajani kehotti minua hakemaan aikuiskasvatuksen ja kehittävän työntutkimuksen tohtoriohjelmaan, ja aloitin tohtoriopinnot vuonna 2010. Tutkimuksessa innostaa mahdollisuus tutkia yhteiskunnallisesti tärkeitä ja merkityksellisiä ilmiöitä.

JOS EN TUTKISI, olisin työssä, joka on samaan aikaan sopivan haastava ja hyvin innostava: opettajana.

AIKUISKASVATUSTIEDETTÄ TARVITAAN yhteiskunnassa, koska maailma ja erityisesti työelämä muuttuvat nopeasti, mikä vaatii sekä yksilöiltä että työyhteisöiltä valmiutta kohdata muutos. Tulevaisuudessa tutkijoiden pitää yhä paremmin pystyä perustelemaan, miksi juuri minun tutkimukseni on tärkeää ja mikä on sen yhteiskunnallinen arvo. Valeuutisten ja kasvavan tiedevastaisuuden aikana tutkijoiden pitää nykyistä aktiivisemmin osallistua julkiseen keskusteluun ja tuoda esiin tuorein tutkimustieto yleistajuisessa, ymmärrettävässä muodossa.

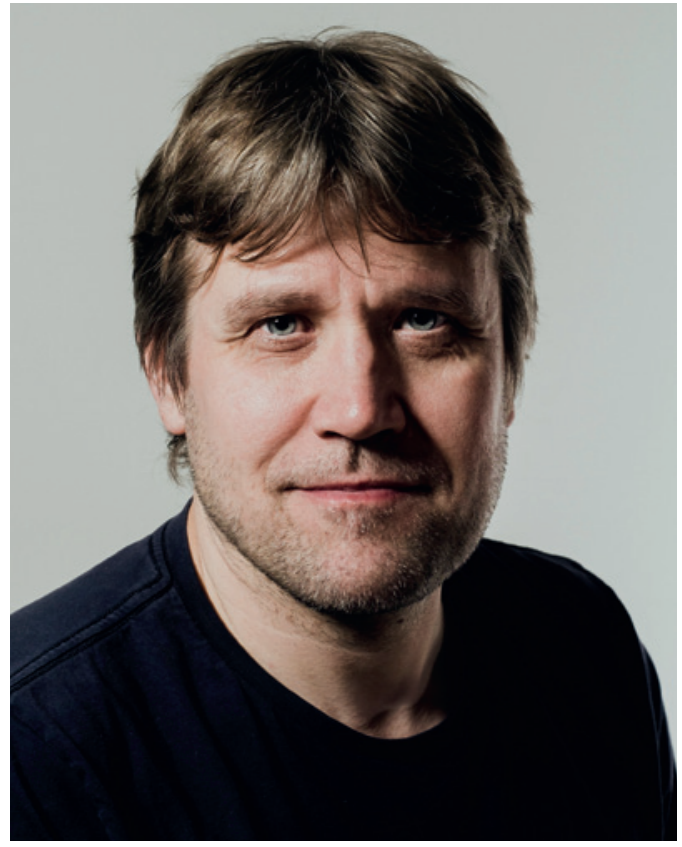

"Ammattien katoaminen, automatisaatio ja tekoälyn kehitys mullistavat tulevaisuudessa työmarkkinoita, mikä korostaa aikuiskasvatuksen merkitystä", väitöskirjatutkija Juhana Rantavuori sanoo. 
PARAIKAA TUTKIN innovatiivista ekspansiivista oppimista työelämän, koulutuksen ja yhteiskunnallisten liikkeiden konteksteissa. Haluan ymmärtää, miten yhteisöt ja organisaatiot kehittelevät ratkaisuja monimutkaisiin ongelmiin, joihin ei ole valmiita vastauksia. Oppimista tapahtuu yhä enemmän virallisten koulutusorganisaatioiden ulkopuolella. On tärkeää ymmärtää oppimisen mekanismeja silloin, kun opiskeltavat asiat eivät ole tarkasti määriteltyjä eivätkä hallittuja. Esimerkiksi yhteiskunnallisiin liikkeisiin osallistuvilla on tavoitteenaan maailman muuttaminen, jolloin oppiminen sulautuu toimintaan. Niissä toimiminen edellyttää tietojen ja taitojen omaksumista, joita koulutusorganisaatiot eivät yleensä tarjoa. Kirjoitan väitöskirjani viimeistä artikkelia, joka perustuu ruuantuotannon parissa toimivasta yhteiskunnallisesta liikkeestä keräämääni aineiston analyysiin.

ESIKUVANANI PIDÄN oppimisen tutkijaa, aikuiskasvatuksen professori emeritusta Yrjö Engeströmiä, joka ohjaa väitöstutkimustani. Hänen laaja-alaisuutensa ja monipuolisuutensa tutkijana sekä halu uudistua ja viedä tutkimusta uusille alueille on toimintamalli, jota haluan omalla tutkijanurallani toteuttaa. Hyödynnän väitöskirjatyössäni kulttuurihistoriallisen toiminnan teorian viitekehystä ja erityisesti Engeströmin kehittämää ekspansiivisen oppimisen teoriaa. Teoria on hyödyllinen, kun tutkitaan tilanteita, joissa organisaatio oppii jotain sellaista, mitä ei vielä ole. Teorian käytännönläheisyys on minulle tärkeä. Sen pohjalta kehitelty muutoslaboratorion menetelmä mahdollistaa työyhteisöjen ja muiden organisaatioiden toiminnan kehittämisen ja parantamisen.

SEURAAVAKSI HALUAN TUTKIA oppimista laajemmin yhteiskunnallisten liikkeiden ja kansalaisaktivismin kentällä. Oppimista on tutkittu paljon koulutusinstituutioissa ja työelämässä, mutta vähemmän kansalaisten omaehtoisessa vaikuttamisessa. Koulutusta ja ammattitaitoa päivitetään yhä enemmän työn ohessa. Ammattiosaaminen ja asiantuntijuus rakentu- vat enenevässä määrin toimijoiden omien intressien, mielenkiinnon kohteiden ja muodollisen koulutuksen yhdistelmänä. Aikuiskasvatukselta vaaditaan tutkimusotetta, jonka avulla tavoitetaan ihmisten arkeen kietoutuvat oppisen ja kehityksen prosessit.

KOLLEGOILTANI SAAN tukea ja sparrausta omien ajatusten kehittelyyn erityisesti, kun omat ideat ovat vasta muotoutumassa. Työpaikkani on toiminnan, kehityksen ja oppimisen tutkimusyksikkö CRADLE Helsingin yliopistossa. Käytäväkeskusteluja ja epämuodollisia, kasvokkaisia kohtaamisia tutkijakollegoiden kanssa ei voi korvata virtuaalisilla kohtaamisilla. Tutkimusyksikköni tohtorikoulu on ollut minulle erityisen tärkeä väylä kokeneiden tutkijoiden yhteisöön.

KUN EN TUTKI, harrastan kaupunkiaktivismia. Toimin ylläpitäjänä Facebookin Lisää kaupunkia Helsinkiin -ryhmässä, jossa edistetään Helsingin kehittymistä nykyistä urbaanimmaksi, tiiviimmäksi ja elävämmäksi kaupungiksi. Olin perustamassa Urban Helsinki -ryhmää, joka on tehnyt useita vaihtoehtoisia kaavaehdotuksia Helsingille. Kaupunkiaktivismi on vastapainoa tutkijan työlle ja antaa samalla näköalapaikan kansalaisaktivismin kentälle, jota omissa tutkimuksissani analysoin. Lisäksi harrastan yksinlaulua ja ruuanlaittoa. Ympärivuotisen työmatkapyöräilyn lasken harrastukseksi, koska se on pienen lapsen isälle oikeastaan ainoa mahdollisuus säännölliseen liikuntaani.

\section{Klassikko, johon palaan}

Professori emeritus Yrjö Engeströmin väitöskirja Learning by Expanding julkaistiin alun perin vuonna 1987. Se on yksi viitatuimpia suomalaisia kasvatustieteen alan kirjoja maailmalla. Sen vaikutus oppimisen, työn ja toiminnan tutkimukseen on ollut merkittävä. Minulle kirja on kulttuurihistoriallisen toiminnan teorian perusteos. Teos sisältää lukuisia teoreettisia ideoita ja avauksia, joiden vuoksi se on yhä mitä ajankohtaisin, vaikka ilmestymisestä on yli 30 vuotta. 